\title{
CLINICAL STUDY ON THE IMPACT OF NUTRITIONAL DEFICIENCY ON THE HEALTH STATUS OF THE SHEEP IN NEW VALLEY GOVERNORATE
}

\author{
S.A. GALBAT ${ }^{1}$; A.M. ABDALLAH ${ }^{1}$; M.A. MAHMOUD ${ }^{2}$ AND \\ MARWA EL-ZEFTAWY ${ }^{3}$ \\ ${ }^{1}$ Animal Medicine Department, Faculty of Veterinary Medicine, New Valley University, New Valley, Egypt \\ ${ }^{2}$ Animal Physiology Department, Faculty of Veterinary Medicine, New Valley University, New Valley, Egypt. \\ ${ }^{3}$ Biochemistry Department, Faculty of Veterinary Medicine, New Valley University, New Valley, Egypt.
}

Received: 20 September 2021; Accepted: 31 October 2021

\begin{abstract}
Sheep production is being encouraged in Egypt as a mean of improving the daily dietary protein intake for humans. Nutritional disorders are considered one of the serious distresses that influence the animal production. The current study aimed to investigate mineral deficiency in sheep and its effect on health status at different New Valley governorate cities. Clinical examination of the sheep was performed. Blood, water and soil samples were collected from different localities. Hematological parameters, serum total protein, albumin, globulin concentrations, kidney function tests and the activity of liver enzymes were estimated. Moreover, the values of some elements in soil and water were determined. Clinical examination showed various symptoms as weight reduction, lameness and eye and skin lesions. The biochemical results exhibited significant reduction of hemoglobin $(\mathrm{Hb})$, mean corpuscular $\mathrm{Hb}$, red blood cell count, hematocrit, lymphocytes, neutrophils, median cells and mean corpuscular $\mathrm{Hb}$ concentration. On the same hand, serum calcium, phosphorus $\left(\mathrm{P}^{3+}\right)$, magnesium $\left(\mathrm{Mg}^{2+}\right)$, copper $\left(\mathrm{Cu}^{2+}\right)$, iron $\left(\mathrm{Fe}^{2+}\right)$ and zinc $\left(\mathrm{Zn}^{2+}\right)$ levels were reduced. Albumin concentration and albumin/globulin ratio were also diminished. There was also significant reduction of serum liver enzymes activity in Paris village. Analyzing of soil reveled decline in concentration of $\mathrm{Mg}^{2+}$ in all studied areas and $\mathrm{Cu}^{2+}$ and $\mathrm{Zn}^{2+}$ in Paris only. However, high values of $\mathrm{P}^{3+}$ and $\mathrm{Fe}^{2+}$ in all localities. Water samples analysis showed low concentrations of $\mathrm{Cu}^{2+}, \mathrm{Zn}^{2+}$ and manganese level. The present study confirmed that mineral deficiencies have great negative impacts on the healthy status of sheep in New Valley governorate.
\end{abstract}

Key words: Sheep; Clinical examination; Minerals; Nutritional deficiency.

\section{INTRODUCTION}

Nutritional deficiency (ND) is a condition that leads to reduce the animal production and obstruct the trade and may

Corresponding author: MARWA EL-ZEFTAWY

E-mail address: marwa@vet.nvu.edu.eg;

marwa_3_1983@yahoo.com

Present address: Biochemistry Department, Faculty of Veterinary Medicine, New Valley University, New Valley, Egypt. severe economic losses occur (Asin et al., 2021). It may be occurred as a consequence of either insufficient diet, impaired absorption, and/or disorder in the metabolic process (Baugreet et al., 2017).

It was reported that macro and microminerals at optimum levels are important for animal growth and protection against some ND diseases. Calcium $\left(\mathrm{Ca}^{2+}\right)$ is one of macro-element that important for muscle 
contraction (Hu et al., 2018), neurotransmission (Williams and Smith, 2018), bone growth and blood clotting (Wasilewski et al., 2019). Phosphorus $\left(\mathrm{P}^{3+}\right)$ is considered the second macro-mineral that crucial for cellular component as nucleic acid, phospholipids and high energy phosphate compounds (Vorland et al., 2017). Additionally, magnesium $\left(\mathrm{Mg}^{2+}\right)$ plays a critical role in activation of kinase and polymerase enzymes (Faraji et al., 2021) and transportation of other cations such as $\mathrm{Ca}^{2+}$, sodium $(\mathrm{Na})$ and potassium across the cell membrane (Mathew and Panonnummal, 2021).

Regarding to micronutrients, it was found that copper $\left(\mathrm{Cu}^{2+}\right)$ is essential for normal growth, hemoglobin $(\mathrm{Hb})$ biosynthesis (Hill and Shannon, 2019) and activating some enzymes as superoxide dismutase, cytochrome $\mathrm{C}$ oxidase and monoamine oxidase (Espinosa and Stein, 2021). Further, iron $\left(\mathrm{Fe}^{2+}\right)$ is another trace element in almost all organisms, as it occupies vital role in $\mathrm{Hb}$ synthesis, neurotransmission (Huang et al., 2018), oxygen transport and DNA synthesis and repair (Ito et al., 2021). On the same hand, the zinc $\left(\mathrm{Zn}^{2+}\right)$ is one of essential trace element acts as an immunostimulant (Maares and Haase, 2016) and has multiple biological functions in growth and reproduction (Driessnack et al., 2017).

Previous studies observed reduction of some macro minerals and microminerals in different cities in Egypt and other countries worldwide. Study of IBRAHIM et al. (2017) in Qena Governorate showed reduction of serum $\mathrm{Ca}^{2+}, \mathrm{Mg}^{2+}, \mathrm{Fe}^{2+}, \mathrm{Cu}^{2+}$, $\mathrm{Zn}^{2+}$ and $\mathrm{P}^{3+}$ by $58.82,49.45,30.09,96.80$, 60.94 and $92.31 \%$, respectively, in sheep suffer from anemia, emaciation, loss of appetite, dehydration, diarrhea and pale mucous membrane. Further Morsy et al. (2020) study in Matrouh governorate noticed reduction of serum $\mathrm{Cu}^{2+}, \mathrm{Zn}^{2+}$ and $\mathrm{Fe}^{2+}$ percentage in sheep suffer from ND by $36.05,68.57$ and $88.37 \%$, respectively. Moreover, ewes suffered from signs of ND exhibited reduction in percentage $\mathrm{Cu}^{2+}$, $\mathrm{Zn}^{2+}, \mathrm{Fe}^{2+}$ and manganese $\left(\mathrm{Mn}^{2+}\right)$ by 77.91 , 40.07, 63.89 and 54.84\% (EL-NASER et al., 2013). On the same hand, sheep had liver trematodes which is one causes of ND exposed decrease in percentage of cobalt $\left(\mathrm{Co}^{2+}\right), \mathrm{Mn}^{2+}$, selenium and $\mathrm{Zn}^{2+}$ by 51.02 , 53.45, 58.21 and 37.15\% (TUNCER et al., 2020). Study of Saleh (2019) also proved reduction of serum $\mathrm{Cu}^{2+}, \mathrm{Zn}^{2+}, \mathrm{Co}^{2+}, \mathrm{Mg}^{2+}$ and $\mathrm{Ca}^{2+}$ in sheep had mineral deficiency in Iraq by $28.89,83.70,53.85,35.58$ and $67.13 \%$, respectively.

The scope of current research is to investigate the ND health problem in sheep and its relation to surrounding environment as soil and water or related to other causes in New Valley governorate. This will be achieved through estimation of hematological and serum level of minerals in sheep suspected to be suffering ND syndrome.

\section{MATERIALS AND METHODS}

\section{Reagents, kits and solutions}

Kits of $\mathrm{Ca}^{2+}, \mathrm{P}^{3+}, \mathrm{Mg}^{2+}, \mathrm{Cu}^{2+}, \mathrm{Fe}^{2+}$ and $\mathrm{Zn}^{2+}$, total protein (TP), albumin, urea and creatinine, alanine aminotransferase (ALT) and aspartate aminotransferase (AST) were obtained from Spectrum Co. (Germany). Diethylenetriamine-pentacetic acid and ammonium acetate were obtained from Sigma Aldrich Co. (USA).

\section{Experimental design}

The study was conducted on 400 sheep, about 1-4 years of age (20-60 kg body weight). Sheep were selected from ElDakhla $(n=100)$, El-Kharga $(n=150)$, and Paris $\quad(n=150)$ cities, New Valley Governorate. The experiment was conducted according to the ethical standards. The study was carried out from October 2020 till March 2021. At first, case history of sheep was recorded, then animal weighing and medical examination were performed. Following that and depending on obtained data from case history and 
clinical examination, 30 animals were selected from each New Valley locality. These animals showed clinical signs of mineral deficiency including easily detached wool, anorexia, and loss of skin rigidity and elasticity, (mineral deficient group). Control healthy animals were selected from each city on the basis of case history, clinical examination (control group).

\section{Clinical examination and blood, soil and water sampling}

Clinical examination of sheep was conducted through examination of body temperature (BT), skin lesions, wool status, mucous membrane alterations, lameness conditions and eye lesions for 400 sheep distributed as following; a hundred animal (50 sheep from El-Kharga, and the 50 from Paris) was excluded. Blood samples were collected from jugular vein $(n=100$ from each city), and all efforts were done to minimize the distress. Blood samples were collected in two types of test tubes, one was with ethylene diamine tetra acetic acid (EDTA) that acts as an anticoagulant and the second was without anticoagulant and kept in an inclined position for 20 minutes at room temperature. Tubes with anticoagulant were kept without centrifugation and used for complete blood picture count (CBC), however the second tubes were centrifuged, and the clear serum was separated and stored at $-20^{\circ} \mathrm{C}$ until analyzed. After $\mathrm{CBC}$, sub-selection from these samples was done $(n=30$ from each locality) for biochemical analysis. Additionally, blood and serum samples were collected from control healthy sheep $(n=30)$. On the other hand, top-soil samples were collected according to Association of Official Analytical Chemists (AOAC) recommendation (Lee, 1995). The collection of soil samples occurred on depth of $25-30 \mathrm{~cm}$ in each area that the animal was fed. Three soil samples were collected from each studied area and sealed in double thickness plastic bags and stored in cool dark condition until time of analysis.
Additionally, water samples were taken from the main source of water in El-Dakhla, El-Kharga and Paris $(n=3$ from each locality) and collected in sterile bottles and sent directly to the laboratory for the biochemical analysis (Hitchens, 1972).

\section{Hematological parameters analysis}

The hematological parameters were estimated in the Research Laboratory, Faculty of Veterinary Medicine, New Valley University, with Auto hematology Analyzer (KT-60, China). These parameters included red blood cell count (RBC), the concentration of $\mathrm{Hb}$, hematocrit (HCT), lymphocytes (LYM), neutrophils (NEU) and median cells (MID) percentage, mean corpuscular volume (MCV), mean corpuscular $\mathrm{Hb}(\mathrm{MCH})$, mean corpuscular $\mathrm{Hb}$ concentration (MCHC), white blood cell count (WBC) and platelets (PLT).

\section{Serum biochemical parameters analysis}

All estimated biochemical parameters were carried out using Biochemistry Analyzer (Prietest COMPACT, India) in the Research Laboratory, Faculty of Veterinary Medicine, New Valley University. Serum $\mathrm{Ca}^{2+}, \mathrm{P}^{3+}, \mathrm{Mg}^{2+}, \mathrm{Cu}^{2+}, \mathrm{Fe}^{2+}$ and $\mathrm{Zn}^{2+}$ concentrations were estimated photometrically according to instructions of kits manufactures. Furthermore, serum total protein (TP), albumin, urea and creatinine concentrations were analyzed. Both globulin concentration and albumin/ globulin $(\mathrm{A} / \mathrm{g})$ ratio were calculated. The activity of liver enzymes, ALT and AST were also determined by kinetic commercial kits and expressed as U/L.

\section{Soil analysis}

The mineral concentration in the soil was analyzed according to Whitehead (1979). In brief, the collected samples were dried at $40^{\circ} \mathrm{C}$ in the oven (DFZ LTD, China), passed through nylon $2 \mathrm{~mm}$ opening sieve and finally grounded in an agate ball mill. The prepared soil was subjected to one of the following treatments either treated by $\mathrm{i}$ : diethylenetriamine-pentacetic acid to 
estimate the levels of $\mathrm{Fe}^{2+}, \mathrm{Mg}^{2+}, \mathrm{Cu}^{2+}$ and $\mathrm{Zn}^{2+}$, or ii: ammonium acetate to analyze $\mathrm{Ca}^{2+}$ and $\mathrm{P}^{3+}$ concentration. The results were compared to reference values of Regional Soil Fertility Coefficients (1999). Soil analysis was done in Regional Laboratory for Water and Soil Analysis at the Directorate of Agriculture in New Valley.

\section{Water analysis}

The water samples were analyzed for $\mathrm{Fe}^{2+}$, $\mathrm{Mn}^{2+}, \mathrm{Cu}^{2+}, \mathrm{Zn}^{2+}$ and $\mathrm{P}^{3+}$ by using computerized atomic absorption technique (GBC-932-AA) air-acetylene type according to manufacture instructions and done by colorimetric titration methods (Laglera and Monticelli, 2017; Özzeybek et al., 2017). The obtained values were expressed in $\mathrm{mg} / \mathrm{L}$. The results were compared to critical level of international standard for drinking water (WHO, 1971). Water analysis technique was performed in Biological Laboratory for Food Analysis, El-Kharga Specialized Hospital.

\section{Statistical analysis}

The obtained data were statistically analyzed using SPSS (Version 25), both descriptive (Mean \pm S.E.) and tests of significance by One way ANOVA (Using Duncan's followed by POST HOC test) were performed. The results were presented as Mean $\pm \mathrm{SE}$ and the significant $\mathrm{P}$ value was set to $<0.05$.

\section{RESULTS}

\section{Clinical examination results}

The data obtained from case history revealed that animals suffered from loss of appetite in percentage 44.0, 16.7 and 23.3 in El-Dakhla, El-Kharga and Paris, respectively. This case history was confirmed by decline in body weight (Bwt) approximately $42.0 \%$ in El-Dakhla, $12.7 \%$ in El-Kharga and $15.3 \%$ in Paris from the total inspected sheep number $(n=100)$ in each locality. Further it was observed presence of Bwt reduction by $62.5,46.0$ and $63.7 \%$ in El-Dakhla, El-Kharga and Paris, respectively when compared to control (Table 1).

Additionally, the clinical examination of sheep exhibited presence of $10.0 \%$ in ElDakhla and 9.3\% in Paris had a higher BT however in El-Kharga all examined sheep were normal. By comparing the BT of sheep in El-Dakhla, El-Kharga and Paris by control, noted that there wasn't any significant difference $(\mathrm{p} \leq 0.05)($ Table 1$)$.

Furthermore, it was observed presence of skin lesions as alopecia, scarp, dark spots, dermatitis and papilloma by 45.0, 3.3 and $11.3 \%$ in El-Dakhla, El-Kharga and Paris, respectively. Concerning to the wool status, mucous membrane and lameness, it was noted presence of multiple alterations respectively as follow, $35.0 \%, 25.0 \%$ and $11.0 \%$ in El-Dakhla, 21.3\%, 6.0\% and 14.0 $\%$ in El-Kharga and 10.0\%, $14.7 \%$ and $5.3 \%$ in Paris from the total inspected sheep $(n=100)$ during our study. Further, it was observed in El-Dakhla and Paris $11.0 \%$ and $14.0 \%$ of sheep respectively were suffered from eye lesions as conjunctivitis and pink eye and there was enlargement of lymph node in $9.0 \%$ and $4.7 \%$ of them, while those two signs were not noticed in ElKharga. Moreover, via observing the nervous manifestation like depression, disorientation, flaccid lip and severe salivation, it was found only $4.0 \%$ in ElDakhla had the signs.

Finally, from all previous clinical examination, we concluded that there was $50.0 \%, 25.0 \%$ and $30.0 \%$ from the examined sheep in El-Dakhla, El-Kharga, and Paris localities ( $n=100$ in each locality), respectively, had a clinical mineral deficiency symptom (Figs.1 and Figs.2).

\section{Hematological analyses in sheep from different localities in New Valley}

The current data exhibited significant reduction of $\mathrm{Hb}$ concentration by 23.4 and $18.4 \%$ in collected samples in El-Dakhla and Paris, respectively compared to control 
group. Additionally, there was significant decline by $10.8 \%$ in El-Dakhla and $4.9 \%$ in Paris when compared to El-Kharga. Further, it was noticed only significant difference in $\mathrm{MCH}$ concentration in ElDakhla comparing to control, El-Kharga and Paris, by 13.7, 6.25 and 3.8-percentage decrease. RBC showed significant decline in samples collected from El-Dakhla by 11.5, 4.7 and 7.1\% compared to control, ElKharga and Paris, respectively. Significant decrease was also observed in PLT in Paris in comparison to control, El-Dakhla and ElKharga approximately $31.2, \quad 32.6$ and 23.0\%. Additionally, HCT and NEU were dropped 16.7 and $60.0 \%$ while LYM was increased by $38.4 \%$ in comparison to control and also, HCT and NEU reduced to 0.07 and 0.72-folds and LYM was increased by 0.7 -fold in comparison to ElKharga and further HCT and NEU were reduced by $10.2 \%$ and 1.3 -fold comparing to Paris, however LYM was increased by $31.5 \%$. Concerning to MID, it was only declined by $31.2 \%$ in El-Dakhla, however elevated by 83.1 and $66.2 \%$ in El-Kharga and Paris, respectively. Additionally, MCHC revealed reduction by $7.8 \%$ compared to control and $6.25 \%$ compared to El-Kharga. Finally, when compared MCHC by RBC in control, El-Dakhla, ElKharga and Paris it was noted an increase level by 76.9, 77.9, 77.5 and $76.1 \%$, respectively. Hematological data was presented in Table (2).

\section{Serum minerals concentration in sheep from different localities in New Valley}

Serum data of mineral analysis in Table (3) revealed that reduction of serum $\mathrm{Ca}^{2+}, \mathrm{P}^{3+}$, $\mathrm{Mg}^{2+}, \mathrm{Cu}^{2+}, \mathrm{Fe}^{2+}$ and $\mathrm{Zn}^{2+}$ by $14.0,28.6$, $67.2,30.4,44.1$ and $16.2 \%$ in El-Dakhla in mineral deficient group, respectively, in comparing to control one. On the other hand, it was reported that $\mathrm{Ca}^{2+}$ concentration was elevated by 7.6 and $8.7 \%$ in El-Kharga when compared to El-Dakhla and Paris. Also, in Paris $\mathrm{P}^{3+}, \mathrm{Cu}^{2+}$ and $\mathrm{Zn}^{2+}$ levels were increased by $21.4,8.2$ and $3.7 \%$ compared to El-Dakhla and by 23.1, 11.4 and $6.1 \%$ compared to El-Kharga.

\section{Serum TP, albumin and globulin concentration and $A / G$ ratio in sheep from different localities in New Valley}

The obtained results in Table (4) showed that there was decrease in TP, albumin and $\mathrm{A} / \mathrm{G}$ ratio in mineral-deficient group compared by control ones, however this reduction was significant in some studied localities and non-significant in others. In El-Kharga, only TP level was significantly decreased by $17.6 \%$ compared to control one and by 10.9 and $15.2 \%$ in comparison to El-Dakhla and Paris. On the same hand, albumin and $\mathrm{A} / \mathrm{G}$ ratio were declined by 26.7 and $33.8 \%$ in El-Dakhla, 41.2 and $46.0 \%$ in El-Kharga and 26.7 and $38.4 \%$ in Paris when compared to control one. Further, globulin concentration in Paris only exhibited elevation by $21.7,7.6$ and $13.0 \%$ in comparison to control, El-Dakhla and El-Kharga, respectively.

\section{Serum urea and creatinine concentration and ALT and AST activity in sheep from different localities in New Valley}

The activity of ALT and AST was determined. It was noted that ALT activity was increased by $39.8 \%$ in Paris, however there was not significant variation in ElDakhla and El-Kharga when compared to control one. Also, ALT was double elevated in Paris by 50.9 and $53.9 \%$, comparing to El-Dakhla and El-Kharga. Moreover, AST activity was only significant raised in Paris by 41.7, 37.5 and $41.1 \%$ compared to control, El-Dakhla and El-Kharga (Table 5).

Serum urea was not significant in studied areas compared to control, while serum creatinine level exhibited significant reduction in El-Kharga by 23.1, 25.1 and $27.9 \%$ comparing to control, El-Dakhla and Paris (Table 5). 

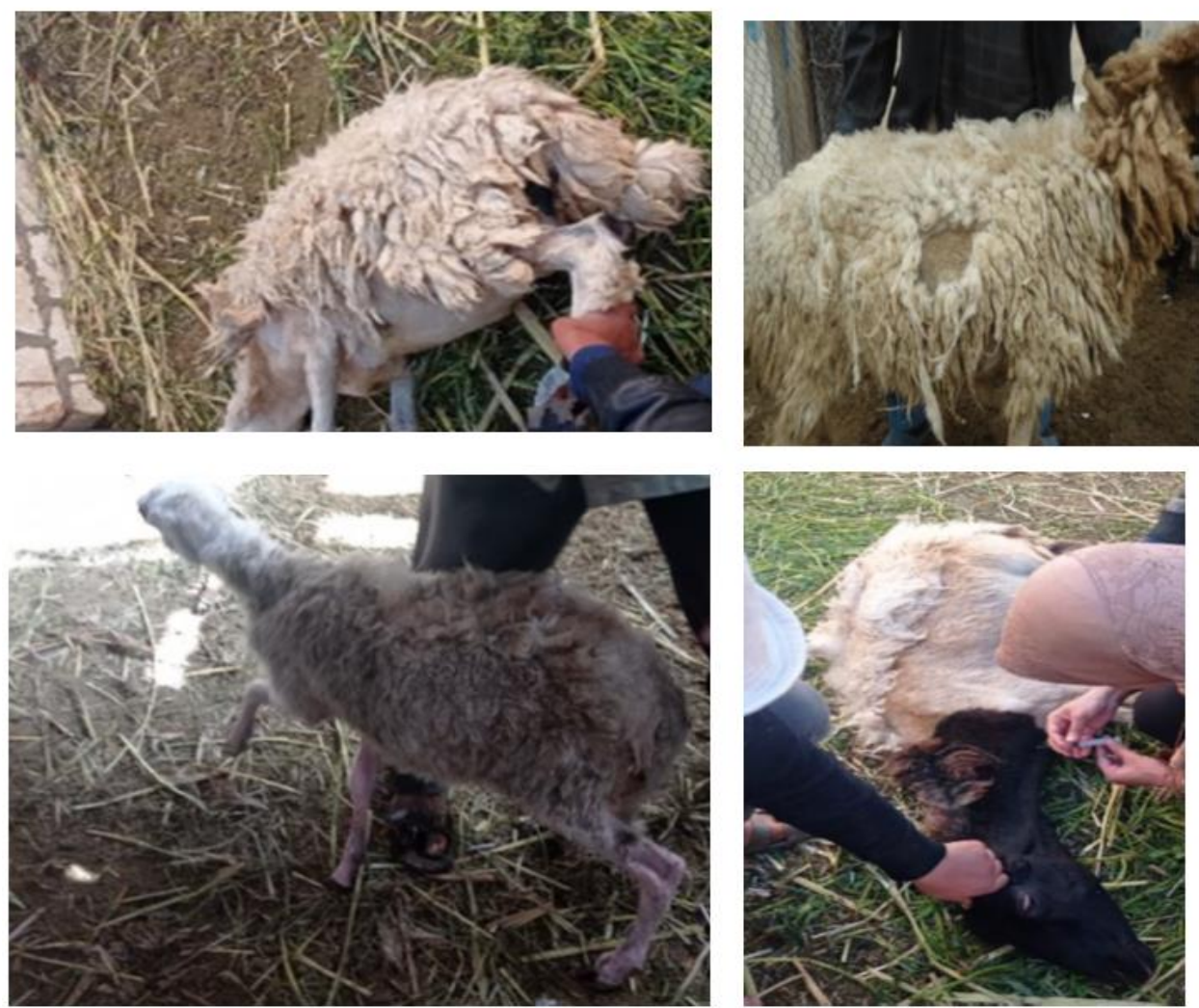

Figs.1: Sheep about 3.5-4 years of age with highly detached wool, alopecia and emaciation.
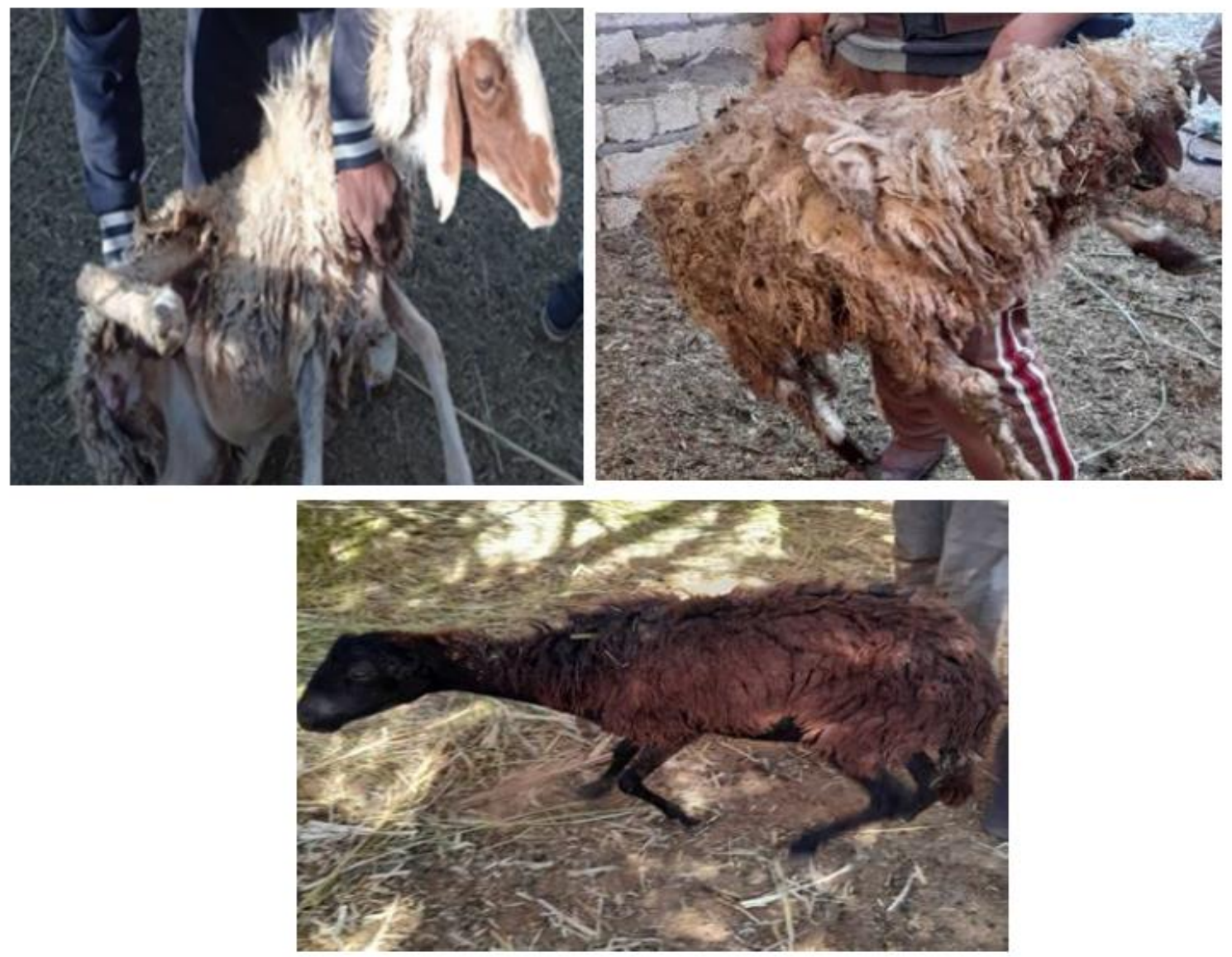

Figs.2: Sheep about 3.5-4 years of age suffer from lameness and emaciation. 
Table 1: Mean values $( \pm$ SE) of Bwt and BT in healthy control and mineral-deficient sheep from different localities in New Valley governorate

\begin{tabular}{lcccc}
\hline & $\begin{array}{c}\text { Control } \\
(\mathbf{n = 1 0 0})\end{array}$ & $\begin{array}{c}\text { El-Dakhla } \\
(\mathbf{n = 1 0 0})\end{array}$ & $\begin{array}{c}\text { El-Kharga } \\
(\mathbf{n = 1 0 0})\end{array}$ & $\begin{array}{c}\text { Paris } \\
(\mathbf{n = 1 0 0})\end{array}$ \\
\hline Bwt $(\mathrm{kg})$ & $48.11 \pm 1.53^{\mathrm{a}}$ & $18.05 \pm 1.17^{\mathrm{b}}$ & $25.98 \pm 0.38^{\mathrm{b}}$ & $17.45 \pm 0.29^{\mathrm{b}}$ \\
\hline BT $\left({ }^{\circ} \mathrm{C}\right)$ & $39.04 \pm 0.10^{\mathrm{a}}$ & $39.74 \pm 0.19^{\mathrm{a}}$ & $39.20 \pm 0.03^{\mathrm{a}}$ & $39.18 \pm 0.09^{\mathrm{a}}$
\end{tabular}

Values represent mean \pm SE. Means with different superscript at the same row are significantly different at $\mathrm{p} \leq 0.05$.

Table 2: Mean values $( \pm$ SE) of hematological parameters in healthy control and mineraldeficient sheep from different localities in New Valley governorate

\begin{tabular}{|c|c|c|c|c|}
\hline & $\begin{array}{l}\text { Control } \\
(n=100)\end{array}$ & $\begin{array}{c}\text { El-Dakhla } \\
(n=100)\end{array}$ & $\begin{array}{c}\text { El-Kharga } \\
(\mathbf{n}=\mathbf{1 0 0})\end{array}$ & $\begin{array}{c}\text { Paris } \\
(n=100)\end{array}$ \\
\hline $\mathrm{RBC}\left(10^{6} / \mathrm{ul}\right)$ & $8.38 \pm 0.08^{\mathrm{a}}$ & $7.42 \pm 0.22^{b}$ & $7.77 \pm 0.20^{\mathrm{a}}$ & $7.98 \pm 0.10^{\mathrm{a}}$ \\
\hline $\mathrm{Hb}(\mathrm{g} / \mathrm{dl})$ & $9.69 \pm 0.14^{\mathrm{a}}$ & $7.42 \pm 0.23^{b}$ & $8.32 \pm 0.23^{\mathrm{a}}$ & $7.91 \pm 0.17^{b}$ \\
\hline $\mathrm{HCT}(\%)$ & $26.93 \pm 0.44^{\mathrm{a}}$ & $22.44 \pm 0.58^{b}$ & $24.10 \pm 0.65^{\mathrm{a}}$ & $24.98 \pm 0.50^{\mathrm{a}}$ \\
\hline MCV (fL) & $32.16 \pm 0.48^{\mathrm{a}}$ & $30.46 \pm 0.69^{\mathrm{a}}$ & $31.17 \pm 1.20^{\mathrm{a}}$ & $31.34 \pm 0.50^{\mathrm{a}}$ \\
\hline $\mathrm{MCH}(\mathrm{pg})$ & $11.64 \pm 0.22^{\mathrm{a}}$ & $10.05 \pm 0.28^{b}$ & $10.72 \pm 0.25^{\mathrm{a}}$ & $10.45 \pm 0.35^{\mathrm{a}}$ \\
\hline $\mathrm{MCHC}(\mathrm{g} / \mathrm{dl})$ & $36.33 \pm 0.75^{\mathrm{a}}$ & $33.51 \pm 0.64^{b}$ & $34.53 \pm 0.84^{\mathrm{a}}$ & $33.35 \pm 0.87^{b}$ \\
\hline WBC $\left(10^{3} / \mathrm{ul}\right)$ & $10.78 \pm 0.74^{\mathrm{a}}$ & $12.33 \pm 0.96^{\mathrm{a}}$ & $9.13 \pm 1.19^{\mathrm{a}}$ & $10.23 \pm 0.42^{\mathrm{a}}$ \\
\hline LYM $\left(10^{3} / \mathrm{ul}\right)$ & $7.91 \pm 0.72^{\mathrm{a}}$ & $10.95 \pm 0.92^{b}$ & $6.43 \pm 0.35^{\mathrm{a}}$ & $7.50 \pm 0.52^{\mathrm{a}}$ \\
\hline $\operatorname{NEU}\left(10^{3} / \mathrm{ul}\right)$ & $2.10 \pm 0.30^{\mathrm{a}}$ & $0.84 \pm 0.20^{\mathrm{b}}$ & $3.07 \pm 0.49^{\mathrm{a}}$ & $1.96 \pm 0.30^{\mathrm{a}}$ \\
\hline $\operatorname{MID}\left(10^{3} / \mathrm{ul}\right)$ & $0.77 \pm 0.22^{\mathrm{a}}$ & $0.53 \pm 0.11^{\mathrm{b}}$ & $1.41 \pm 0.09^{\mathrm{c}}$ & $1.28 \pm 0.20^{\mathrm{c}}$ \\
\hline PLT (k/ul) & $678.2 \pm 52.83^{a}$ & $692.2 \pm 48.48^{a}$ & $605.2 \pm 68.18^{a}$ & $466.3 \pm 30.77^{b}$ \\
\hline
\end{tabular}

Values represent mean \pm SE. Means with different superscript at the same row are significantly different at $\mathrm{p} \leq 0.05$

Table 3: Mean values ( \pm SE) of serum minerals concentrations in healthy control and mineral-deficient sheep from different localities in New Valley governorate

\begin{tabular}{lcccc}
\hline & $\begin{array}{c}\text { Control } \\
(\mathbf{n = 3 0})\end{array}$ & $\begin{array}{c}\text { El-Dakhla } \\
(\mathbf{n = 3 0})\end{array}$ & $\begin{array}{c}\text { El-Kharga } \\
(\mathbf{n = 3 0})\end{array}$ & $\begin{array}{c}\text { Paris } \\
(\mathbf{n = 3 0})\end{array}$ \\
\hline $\mathrm{Ca}^{2+}(\mathrm{mg} / \mathrm{dl})$ & $8.93 \pm 0.12^{\mathrm{a}}$ & $7.68 \pm 0.23^{\mathrm{b}}$ & $8.26 \pm 0.12^{\mathrm{a}}$ & $7.60 \pm 0.23^{\mathrm{b}}$ \\
\hline $\mathrm{P}^{3+}(\mathrm{mg} / \mathrm{dl})$ & $4.12 \pm 0.27^{\mathrm{a}}$ & $2.94 \pm 0.18^{\mathrm{b}}$ & $2.90 \pm 0.21^{\mathrm{b}}$ & $3.57 \pm 0.25^{\mathrm{a}}$ \\
\hline $\mathrm{Mg}^{2+}(\mathrm{mg} / \mathrm{dl})$ & $0.64 \pm 0.07^{\mathrm{a}}$ & $0.21 \pm 0.03^{\mathrm{b}}$ & $0.28 \pm 0.07^{\mathrm{b}}$ & $0.27 \pm 0.05^{\mathrm{b}}$ \\
\hline $\mathrm{Cu}^{2+}(\mu \mathrm{g} / \mathrm{dl})$ & $110.30 \pm 6.34^{\mathrm{a}}$ & $76.79 \pm 5.66^{\mathrm{b}}$ & $74.59 \pm 2.82^{\mathrm{b}}$ & $83.12 \pm 6.86^{\mathrm{c}}$ \\
\hline $\mathrm{Fe}^{2+}(\mu \mathrm{g} / \mathrm{dl})$ & $109.60 \pm 11.57^{\mathrm{a}}$ & $61.24 \pm 8.75^{\mathrm{b}}$ & $55.61 \pm 1.08^{\mathrm{b}}$ & $58.49 \pm 5.15^{\mathrm{b}}$ \\
\hline $\mathrm{Zn}^{2+}(\mu \mathrm{g} / \mathrm{dl})$ & $98.81 \pm 2.72^{\mathrm{a}}$ & $82.85 \pm 3.20^{\mathrm{b}}$ & $80.96 \pm 2.71^{\mathrm{b}}$ & $85.88 \pm 2.76^{\mathrm{a}}$ \\
\hline $\mathrm{Vas}^{\mathrm{m}}$ & &
\end{tabular}

Values represent mean \pm SE. Means with different superscript at the same row are significantly different at $\mathrm{p} \leq 0.05$. 
Table 4: Mean values ( \pm SE) of serum TP, albumin and globulin concentration and A/G ratio in healthy control and mineral-deficient sheep from different localities in New Valley governorate

\begin{tabular}{llccc}
\hline & $\begin{array}{c}\text { Control } \\
(\mathbf{n}=\mathbf{3 0})\end{array}$ & $\begin{array}{c}\text { El-Dakhla } \\
(\mathbf{n = 3 0})\end{array}$ & $\begin{array}{c}\text { El-Kharga } \\
(\mathbf{n = 3 0})\end{array}$ & $\begin{array}{c}\text { Paris } \\
(\mathbf{n = 3 0})\end{array}$ \\
\hline $\mathrm{TP}(\mathrm{g} / \mathrm{dl})$ & $7.26 \pm 0.21^{\mathrm{a}}$ & $6.71 \pm 0.11^{\mathrm{a}}$ & $5.98 \pm 0.08^{\mathrm{b}}$ & $7.05 \pm 0.15^{\mathrm{a}}$ \\
\hline Albumin $(\mathrm{g} / \mathrm{dl})$ & $3.74 \pm 0.12^{\mathrm{a}}$ & $2.74 \pm 0.09^{\mathrm{b}}$ & $2.20 \pm 0.13^{\mathrm{b}}$ & $2.78 \pm 0.10^{\mathrm{b}}$ \\
\hline Globulin $(\mathrm{g} / \mathrm{dl})$ & $3.51 \pm 0.17^{\mathrm{a}}$ & $3.97 \pm 0.10^{\mathrm{a}}$ & $3.78 \pm 0.14^{\mathrm{a}}$ & $4.27 \pm 0.09^{\mathrm{b}}$ \\
\hline A/G ratio & $1.05 \pm 0.77^{\mathrm{a}}$ & $0.70 \pm 0.04^{\mathrm{b}}$ & $0.57 \pm 0.04^{\mathrm{b}}$ & $0.65 \pm 0.02^{\mathrm{b}}$ \\
\hline
\end{tabular}

Values represent mean \pm SE. Means with different superscript at the same row are significantly different at $\mathrm{p} \leq 0.05$.

Table 5: Mean values $( \pm$ SE) of serum liver enzymes activity and kidney function tests in healthy control and mineral-deficient sheep from different localities in New Valley governorate

\begin{tabular}{lcccc}
\hline & $\begin{array}{c}\text { Control } \\
(\mathbf{n = 3 0})\end{array}$ & $\begin{array}{c}\text { El-Dakhla } \\
(\mathbf{n = 3 0})\end{array}$ & $\begin{array}{c}\text { El-Kharga } \\
(\mathbf{n = 3 0})\end{array}$ & $\begin{array}{c}\text { Paris } \\
(\mathbf{n = 3 0})\end{array}$ \\
\hline ALT $(\mathrm{U} / \mathrm{L})$ & $21.16 \pm 1.12^{\mathrm{a}}$ & $19.60 \pm 0.84^{\mathrm{a}}$ & $19.22 \pm 1.13^{\mathrm{a}}$ & $29.58 \pm 1.48^{\mathrm{b}}$ \\
\hline AST $(\mathrm{U} / \mathrm{L})$ & $26.38 \pm 1.32^{\mathrm{a}}$ & $27.17 \pm 0.82^{\mathrm{a}}$ & $26.48 \pm 1.75^{\mathrm{a}}$ & $37.37 \pm 1.48^{\mathrm{b}}$ \\
\hline Urea $(\mathrm{mg} / \mathrm{dl})$ & $46.09 \pm 2.05^{\mathrm{a}}$ & $53.00 \pm 4.47^{\mathrm{a}}$ & $39.50 \pm 1.89^{\mathrm{a}}$ & $53.48 \pm 3.16^{\mathrm{a}}$ \\
\hline Creatinine $(\mathrm{mg} / \mathrm{dl})$ & $1.09 \pm 0.06^{\mathrm{a}}$ & $1.12 \pm 0.06^{\mathrm{a}}$ & $0.84 \pm 0.03^{\mathrm{b}}$ & $1.16 \pm 0.04^{\mathrm{a}}$ \\
\hline
\end{tabular}

Values represent mean \pm SE. Means with different superscript at the same row are significantly different at $\mathrm{p} \leq 0.05$.

Table 6: Extractable mineral concentrations in soil from different localities in New Valley governorate

\begin{tabular}{|c|c|c|c|c|c|c|c|}
\hline & & $\begin{array}{l}\mathrm{Ca}^{2+} \\
(\mathrm{mEq} / 100 \mathrm{~g})\end{array}$ & $\begin{array}{l}\mathbf{P}^{3+} \\
(\mathbf{p p m})\end{array}$ & $\begin{array}{l}\mathrm{Mg}^{2+} \\
(\mathrm{ppm})\end{array}$ & $\begin{array}{l}\mathrm{Cu}^{2+} \\
(\mathrm{ppm})\end{array}$ & $\begin{array}{l}\mathrm{Fe}^{2+} \\
(\mathrm{ppm})\end{array}$ & $\begin{array}{l}\mathrm{Zn}^{2+} \\
(\mathbf{p p m})\end{array}$ \\
\hline \multicolumn{2}{|c|}{ El-Dakhla $(n=3)$} & $4.2^{\mathrm{N}}$ & $30.6^{\mathrm{H}}$ & $4.92^{\mathrm{L}}$ & $4.58^{\mathrm{H}}$ & $78.0^{\mathrm{H}}$ & $4.7^{\mathrm{H}}$ \\
\hline \multicolumn{2}{|c|}{ El-Kharga $(n=3)$} & $4.9^{\mathrm{N}}$ & $32.2^{\mathrm{H}}$ & $5.66^{\mathrm{L}}$ & $3.2^{\mathrm{H}}$ & $21.0^{\mathrm{H}}$ & $2.08^{\mathrm{H}}$ \\
\hline \multicolumn{2}{|l|}{ Paris $(n=3)$} & $2.8^{\mathrm{N}}$ & $21.3^{\mathrm{H}}$ & $2.0^{\mathrm{L}}$ & $0.4^{\mathrm{L}}$ & $10.52^{\mathrm{H}}$ & $0.88^{\mathrm{L}}$ \\
\hline \multirow{3}{*}{$\begin{array}{l}\text { Reference } \\
\text { values }\end{array}$} & $\mathrm{L}$ & $<2.4$ & $<10.0$ & $<50$ & $<0.5$ & $<4.0$ & $<1.0$ \\
\hline & $\mathrm{N}$ & $2.4-5$ & $11-15$ & $50-70$ & $0.5-1.0$ & $4.0-6.0$ & $1.0-2.0$ \\
\hline & $\mathrm{H}$ & $>5$ & $>15$ & $>70$ & $>1.0$ & $>6.0$ & $>5.0$ \\
\hline
\end{tabular}

Values with superscripts (L) is lower than reference values of Regional Soil Fertility Coefficients, $(\mathrm{N})$ is the normal reference values of Regional Soil Fertility Coefficients and $(\mathrm{H})$ is higher than reference values of Regional Soil Fertility Coefficients. 
Table 7: Mineral concentrations in water from different localities in New Valley governorate

\begin{tabular}{cllllc}
\hline & $\begin{array}{l}\mathbf{C a}^{2+} \\
\text { carbonate } \\
(\mathbf{m g} / \mathbf{L})\end{array}$ & $\begin{array}{l}\mathbf{F e}^{2+} \\
(\mathbf{m g} / \mathbf{L})\end{array}$ & $\begin{array}{l}\mathbf{C u}^{2+} \\
(\mathbf{m g} / \mathbf{L})\end{array}$ & $\begin{array}{l}\mathbf{Z n}^{2+} \\
(\mathbf{m g} / \mathbf{L})\end{array}$ & $\begin{array}{l}\mathbf{M n} \\
(\mathbf{m g} / \mathbf{L})\end{array}$ \\
\hline El-Dakhla $(\mathrm{n}=3)$ & $12^{\mathrm{L}}$ & $0.5^{\mathrm{N}}$ & $<0.1^{\mathrm{L}}$ & $<0.1^{\mathrm{L}}$ & $<0.1^{\mathrm{L}}$ \\
\hline El-Kharga $(\mathrm{n}=3)$ & $16^{\mathrm{L}}$ & $0.4^{\mathrm{N}}$ & $<0.1^{\mathrm{L}}$ & $<0.1^{\mathrm{L}}$ & $<0.1^{\mathrm{L}}$ \\
\hline Paris $(\mathrm{n}=3)$ & $32^{\mathrm{L}}$ & $0.3^{\mathrm{N}}$ & $<0.1^{\mathrm{L}}$ & $<0.1^{\mathrm{L}}$ & $<0.1^{\mathrm{L}}$ \\
\hline Critical levels & 500 & 0.3 & 2.0 & 3.0 & 0.4 \\
\hline
\end{tabular}

Values with superscripts (L) is lower than the critical levels of international standard of drinking water (WHO, 1971), respectively and $(\mathrm{N})$ is the normal critical level of international standard of drinking water (WHO, 1971).

\section{DISCUSSION}

Nutrients are crucial for the general body health. They offer the needed raw materials for different tissues. Among these nutrients, the trace elements which have an important role in various biochemical reactions, as they act as cofactors for many enzymes (Nwosu, 2019). Both macro and micronutrients obtained from diet, minerals and vitamins are important micro-nutrients that required in trace amount stimulating necessary different biological reaction for cell metabolism in livestock (Lee et al., 2002). Minerals contents and balance are important for productive and reproductive life of small ruminant (Vázquez-Armijo et al., 2011). Minerals perform chief biological and physiological role (Nwosu, 2019). Undesirable effect and health problems may result from decreased mineral feed concentrations, absorption and bioavailability (Arshad et al., 2021).

The present study disclosed that animals under investigation acquired significant mineral deficiency. This greatly affects health status of examined animals. Our results showed a significant reduction of serum $\mathrm{Ca}^{2+}, \mathrm{P}^{3+}, \mathrm{Mg}^{2+}, \mathrm{Cu}^{2+}, \mathrm{Fe}^{2+}$ and $\mathrm{Zn}^{2+}$ concentrations $(\mathrm{p} \leq 0.05)$ in El-Dakhla locality. Those minerals concentrations except $\mathrm{Ca}^{2+}$ were also less than control in El-Kharga locality. However, in Paris locality $\mathrm{P}^{3+}$ and $\mathrm{Zn}^{2+}$ concentrations were not significant.
Regarding to serum $\mathrm{Zn}^{2+}$ concentration, the current study revealed a decrease in serum $\mathrm{Zn}^{2+}$ concentration, led to physiological defects accompanied with wide range of disorders, including anorexia, weight loss, growth retardation, skin lesions, swelling of the eye lid, alopecia and dermatitis, this finding matches with the results obtained by Sloup et al. (2017). Concurrently joint stiffness and reduction in the hematological parameters were recorded. This finding agreed with the observation of Song and Shen (2020), who attributed this disturbance to the decline in some $\mathrm{Zn}^{2+}$ dependent metabolic enzymes as alkaline phosphatase and lactic acid dehydrogenase. Fertility wise, our study clinically revealed marked reduction in both male and female fertility these findings support the outcome presented by Najafzadeh et al. (2013) who stated that there is marked fertility reduction in ruminant suffering $\mathrm{Zn}^{2+}$ deficiency (Tables 2 and 3).

The current study revealed reduction of serum $\mathrm{Cu}^{2+}$ in all studied areas. This led to anemia, poor growth, wool keratinization and bone disorders of sheep. These findings agreed with Mandour et al. (2021). $\mathrm{Cu}^{2+}$ deficiency reduce $\mathrm{Fe}^{2+}$ absorption from the gut as $\mathrm{Cu}^{2+}$ can modulate the hephaestin-a multi- $\mathrm{Cu}^{2+}$ oxidase required for optimal $\mathrm{Fe}^{2+}$ absorption (Matak et al., 2013). This fact justifies the reduced appetite, emaciation, unsteady gait of sheep suffering from serum $\mathrm{Cu}^{2+}$ decrease. This finding goes with the postulate of Wu et al. (2020) who assured the decreased performance, 
appetite, anemia and economic losses due to hypocupermia. The deficiency of $\mathrm{Cu}^{2+}$ may be attributed to high concentration of other elements (Thorndyke et al., 2021) as molybdenum (MO) and sulfur (S) in the soil which lead to formation of $\mathrm{MO}-\mathrm{Cu}^{2+}$ or $\mathrm{S}-\mathrm{Cu}^{2+}$ complex which are poorly absorbed via the intestine. Moreover, some authors (Abramowicz et al., 2019; Shen and Song 2021) attributed serum $\mathrm{Cu}^{2+}$ decline to its decrease in the soil and forage. This finding assures this study notice in Paris locality. In this respect, some authors (Wu et al., 2020) stated that, hypocupermia not only depends on the total $\mathrm{Cu}^{2+}$ contents but also it is greatly dependent on other factors affecting absorption and utilization so, $\mathrm{Cu}^{2+}$ deficiency has negative impact (Table 3 ).

$\mathrm{Ca}^{2+}$ and $\mathrm{P}^{3+}$, are two major component minerals of the ruminant body. They play a major role in neuro transmission and other metabolic activities, besides $\mathrm{P}^{3+}$ is key element in maintaining acid-base balance, and consider vital element in energy skeleton within the animal body (Yano et al., 1991). It also important for ruminal microbial fermentation and protein synthesis and the insufficient dietary $\mathrm{P}^{3+}$ affect digestibility (Puggaard et al., 2011). Hypocalcemia and hypophosphatemia are partially common in ruminant (Goff, 2000).

Prolonged dry period with dead pasture may cause low $\mathrm{P}^{3+}$ level. This results decreased the growth and production and caused bone softness, lameness and reduced the appetite (Masters and White, 1996). This finding agreed with our result which showed decreased serum concentration of $\mathrm{P}^{3+}$ level. Furthermore osteoporosis and decrease bone density, increased fracture risk accompany marked $\mathrm{Ca}^{2+}$ deficiency (Theobald, 2005). Common symptoms of reduced $\mathrm{Ca}^{2+}$ level are reduced growth rate and milk production, enlarged joints, tremors and general inertia (Masters and White, 1996) (Table 3).

The current study showed decrease of serum $\mathrm{Fe}^{2+}$ concentration that causes decline in the most hematological parameters. This come in accordance with Yatoo et al. (2013), who stated that $\mathrm{Fe}^{2+}$ deficiency influences the performance and production of sheep. Several reasons of $\mathrm{Fe}^{2+}$ deficiency, though its higher level in soil and normal in drinking water as affection of the sheep with infectious agent (Kojouri and Shirazi, 2007), and fascioliasis (Kojouri et al., 2013). This may be a defensive mechanism made by the body, in which the $\mathrm{Fe}^{2+}$ is sequestered from circulation into storage form primarily in liver and bone marrow in trail to make the $\mathrm{Fe}^{2+}$ unavailable to the pathogens to limit its activities and growth, however this negatively affect the process of erythropoiesis (Carlson, 1996) (Tables 2, 3, 6 and 7).

Additionally, it was observed that several factors can affect $\mathrm{Mg}^{2+}$ absorption and utilization in ruminant, like parathyroid hormone that decreasing its urinary excretion and stimulating bone resorption, thus releasing $\mathrm{Mg}^{2+}$ into the extracellular fluid, $\mathrm{Mg}^{2+}$ urinary excretion and absorption from the gastrointestinal tract which may be due to high dietary $\mathrm{K}^{+}$that decrease the $\mathrm{Mg}^{2+}$ absorption (Hardwick et al., 1991). The reported hypomagnesemia in our study was chiefly due to low intake of $\mathrm{Mg}^{2+}$ in food. This was confirmed by presence of low $\mathrm{Mg}^{2+}$ level in soil. This finding matches results obtained by Kumssa et al. (2019) and higher $\mathrm{Ca}^{2+}$ and $\mathrm{Na}$ intake. This agreed with Pickering et al. (2020) (Tables 3 and 6).

Proper digestion in rumen is important key factor for animal general health, proper protein fermentation which is the key factor for liver albumin and globulin production. It was noted the importance of minerals in normal rumen function. These co-enzymes possess potential role in binding pathogenic microorganisms and toxic compounds (Saleem et al., 2012), possibly, due to their high adsorption capacity (Slamova et al., 2011) (Table 4). Hepatocyte integrity can be monitored via AST and ALT levels 
(Bobe et al., 2004), where lower minerals concentration negatively affect ruminal micro-flora, this may lead to production of toxic products (Wang et al., 2013). Increasing liver enzymes either direct through increased liver detoxification due to toxic load or indirect because of increase oxidative stress (Guo et al., 2017) (Table 5). Similarly Slamova et al. (2011) attributed the beneficial role of mineral on liver due to its high capability of toxic adsorption, this facts agree with this study results that showed decreased liver activity and lower albumin, globulin as well as increased in liver enzymes.

\section{CONCLUSIONS}

Current study showed that, naturally grazed sheep in different New Valley localities, exhibit variable degrees of serum minerals deficiency that led to marked deceases in performance, blood parameters. Therefore, regulatory examination and monitoring health status are recommended to increase the economical profit and production of these animals.

\section{ACKNOWLEDGMENTS}

The authors thank all farms owners for their help during samples collection. The authors extend their thanks to staff members of Regional Laboratory for Water and Soil Analysis at the Directorate of Agriculture in New Valley and Biological Laboratory for food analysis, El-Kharga Specialized Hospital

\section{CONFLICT OF INTEREST DISCLOSURE}

The authors declare no conflicts of interest associated with this manuscript.

\section{REFERENCES}

Abramowicz, B.; Kurek, L.; Debiak, P.; Madany, J. and Lutnicki, K. (2019): Hematological parameters in dairy cows with copper deficiency. Journal of Elementology, 24(2).

Arshad, M.A.; Ebeid, H.M. and Hassan, F.U. (2021): Revisiting the Effects of Different Dietary Sources of Selenium on the Health and Performance of Dairy Animals: a Review. Biol Trace Elem Res, 199(9), 3319-3337. doi:10.1007/s12011-02002480-6

Asin, J.; Ramirez, G.A.; Navarro, M.A.; Nyaoke, A.C.; Henderson, E.E.; Mendonca, F.S.; Molin, J. and Uzal, F.A. (2021): Nutritional Wasting Disorders in Sheep. Animals (Basel), 11(2). doi:10.3390/ani11020501

Baugreet, S.; Hamill, R.M.; Kerry, J.P. and McCarthy, S.N. (2017): Mitigating Nutrition and Health Deficiencies in Older Adults: A Role for Food Innovation? J Food Sci, 82(4), 848855. doi:10.1111/1750-3841.13674

Bobe, G.; Young, J.W. and Beitz, D.C. (2004): Invited review: pathology, etiology, prevention, and treatment of fatty liver in dairy cows. Journal of dairy science, 87(10), 3105-3124.

Carlson, G.P. (1996): Depression anemia. Large Animal Internal Medicine, 2nd ed., Mosby, Saint Louis, Missouri, 1231-1233.

Driessnack, M.K.; Jamwal, A. and Niyogi, S. (2017): Effects of chronic waterborne cadmium and zinc interactions on tissue-specific metal accumulation and reproduction in fathead minnow (Pimephales promelas). Ecotoxicol Environ Saf, 140, 65-75. doi:10.1016/j.ecoenv. 2017.02 .023

El-Naser, E.M.A.; Mohamed, G.A.E. and Rateb, M.H. (2013): Wool analysis as an indicator for diagnosis of some trace elements deficiency in sheep. Assiut Vet. Med. J., 59(137), 120-123.

Espinosa, C.D. and Stein, H.H. (2021): Digestibility and metabolism of copper in diets for pigs and influence of dietary copper on growth performance, intestinal health, and overall immune status: a review. $J$ 
Anim Sci Biotechnol, 12(1), 13. doi:10.1186/s40104-020-00533-3.

Faraji, S.; Ahmadizadeh, M. and Heidari, $P$. (2021): Genome-wide comparative analysis of $\mathrm{Mg}$ transporter gene family between Triticum turgidum and Camelina sativa. Biometals, 34(3), 639-660. doi:10.1007/s 10534021-00301-4.

Goff, J.P. (2000): Pathophysiology of calcium and phosphorus disorders. Veterinary Clinics of North America: Food Animal Practice, 16(2), 319337.

Guo, J.; Chang, G.; Zhang, K.; Xu, L.; Jin, D.; Bilal, M.S. and Shen, X. (2017): Rumen-derived lipopolysaccharide provoked inflammatory injury in the liver of dairy cows fed a highconcentrate diet. Oncotarget, 8(29), 46769.

Hardwick, L.L.; Jones, M.R.; Brautbar, N. and Lee, D.B.N. (1991): Magnesium absorption: mechanisms and the influence of vitamin $\mathrm{D}$, calcium and phosphate. The Journal of nutrition, 121(1), 13-23.

Hill, G.M. and Shannon, M.C. (2019): Copper and Zinc Nutritional Issues for Agricultural Animal Production. Biol Trace Elem Res, 188(1), 148159. doi:10.1007/s12011-018-1578-5.

Hitchens, R.A.N. (1972): International Standards for Drinking Water. British Journal of Industrial Medicine, 29(3), 349.

Hu, G.Y.; Peng, C.; Xie, X.F.; Xiong, L.; Zhang, S.Y. and Cao, X.Y. (2018): Patchouli alcohol isolated from Pogostemon cablin mediates endothelium-independent

vasorelaxation by blockade of $\mathrm{Ca}(2+)$ channels in rat isolated thoracic aorta. J Ethnopharmacol, 220, 188-196. doi: 10.1016/j.jep.2017.09.036

Huang, X.T.; Liu, X.; Ye, C.Y.; Tao, L.X.; Zhou, H. and Zhang, H.Y. (2018): Iron-induced energy supply deficiency and mitochondrial fragmentation in neurons. $J$
Neurochem, 147(6), 816-830. doi: 10.1111/jnc.14621.

Ibrahim, M.I.; Mohamed, A.E.A.; Ali, A.O. and Mahmoud, H.Y.A.H. (2017): Estimation of some trace elements in healthy and diseased sheep in qena governorate. Assiut Vet. Med. J., 63(152), 183-188.

Ito, H.; Kurokawa, $H$. and Matsui, $H$. (2021): Mitochondrial reactive oxygen species and heme, non-heme iron metabolism. Arch Biochem Biophys, 700, 108695. doi:10.1016/ j.abb.2020.108695

Kojouri, G.A.; Jalali, Y.; Shojai, J.; Shahnamnia, $M$. and Kojouri, A. (2013): Comparing serum and hepatic concentrations of iron, copper, and cobalt in healthy sheep and sheep with chronic fasciolosis. Comparative Clinical Pathology, 22(1), 141-145.

Kojouri, G.A. and Shirazi, A. (2007): Serum concentrations of $\mathrm{Cu}, \mathrm{Zn}, \mathrm{Fe}$, $\mathrm{Mo}$ and $\mathrm{Co}$ in newborn lambs following systemic administration of vitamin $\mathrm{E}$ and selenium to the pregnant ewes. Small Ruminant Research, 70(2-3), 136-139.

Kumssa, D.B.; Penrose, B.; Bone, P.A.; Lovatt, J.A.; Broadley, M.R.; Kendall, N.R. and Ander, E.L. (2019): A reconnaissance survey of farmers' awareness of hypomagnesaemic tetany in UK cattle and sheep farms. PLoS One, 14(10), e0223868. doi: 10.1371/journal.pone.0223868.

Laglera, L.M. and Monticelli, D. (2017): Iron detection and speciation in natural waters by electrochemical techniques: A critical review. Current Opinion in Electrochemistry, 3(1), 123-129.

doi:10.1016/j.coelec.2017.07.007.

Lee, J.; Knowles, S.O. and Judson, G.J. (2002): Trace element and vitamin nutrition of grazing sheep. Sheep Nutrition. Wallingford: $\quad C A B$ International, 285-311.

Lee, M.H. (1995): Official methods of analysis of AOAC International (16th edn): edited by Patricia A. Cunniff, 
AOAC International, 1995. \$359.00

(North America)/\$399.00 (elsewhere) (xxvi+ 1899 pages) ISBN 0935584 544 (Vol. 382): Elsevier.

Maares, M. and Haase, H. (2016): Zinc and immunity: An essential interrelation. Arch Biochem Biophys, 611, 58-65. doi:10.1016/j.abb.2016.03.022

Mandour, A.S.; Elsayed, R.F.; Ali, A.O.; Mahmoud, A.E.; Samir, H.; Dessouki, A.A.; Matsuura, K.; Watanabe, I.; Sasaki, K.; Al-Rejaie, S.; Yoshida, T.; Shimada, K.; Tanaka, $R$. and Watanabe, G. (2021): The utility of electrocardiography and echocardiography in copper deficiency-induced cardiac damage in goats. Environ Sci Pollut Res Int, 28(7), 7815-7827. doi:10.1007/s 11356-020-11014-5.

Masters, D.G. and White, C.L. (1996): Detection and treatment of mineral nutrition problems in grazing sheep. Retrieved from.

Matak, P.; Zumerle, S.; Mastrogiannaki, M.; El Balkhi, S.; Delga, S.; Mathieu, J.R.R.; Canonne-Hergaux, F.; Poupon, J.; Sharp, P.A. and Vaulont, $S$. (2013): Copper deficiency leads to anemia, duodenal hypoxia, upregulation of HIF-2 $\alpha$ and altered expression of iron absorption genes in mice. PLoS One, 8(3), e59538.

Mathew, A.A. and Panonnummal, $R$. (2021): 'Magnesium'-the master cation-as a drug-possibilities and evidences. Biometals, 1-32. doi: 10.1007/s10534-021-00328-7

Morsy, M.M.; El-Ghannam, A.-E.A.; Saleh, S.Y. and Arafa3, M.M. (2020): Assessing of Heavy Metals in Serum of Barki Sheep in Rainfed Area at Matrouh Governorate. Journal of Veterinary Medical Research, 27(1), 5-17.

Najafzadeh, $\quad$ H.; Ghoreishi, $\quad$ S.M.; Mohammadian, B.; Rahimi, E.; Afzalzadeh, $\quad$ M.R.; Kazemivarnamkhasti, M. and Ganjealidarani, H. (2013): Serum biochemical and histopathological changes in liver and kidney in lambs after zinc oxide nanoparticles administration. Veterinary World, $6(8)$.

Nwosu, O. (2019): A systematic review of the impact of minerals on pregnant sheep and goats and their offspring in the African continent. University of Pretoria.

Özzeybek, G.; Erarpat, S.; Chormey, D.S.; Fırat, M.; Büyükpınar, Ç.; Turak, F. and Bakırdere, S. (2017): Sensitive determination of copper in water samples using dispersive liquid-liquid microextraction-slotted quartz tubeflame atomic absorption spectrometry. Microchemical Journal, 132, 406-410. doi:10.1016/ j.microc.2017.02.031

Pickering, G.; Mazur, A.; Trousselard, M.; Bienkowski, P.; Yaltsewa, N.; Amessou, M.; Noah, L. and Pouteau, E. (2020): Magnesium Status and Stress: The Vicious Circle Concept Revisited. Nutrients, 12(12). doi: 10.3390/nu12123672

Puggaard, L.; Kristensen, N.B. and Sehested, J. (2011): Effect of decreasing dietary phosphorus supply on net recycling of inorganic phosphate in lactating dairy cows. Journal of dairy science, 94(3), 14201429.

Saleem, F.; Ametaj, B.N.; Bouatra, S.; Mandal, R.; Zebeli, Q.; Dunn, S.M. and Wishart, D.S. (2012): A metabolomics approach to uncover the effects of grain diets on rumen health in dairy cows. Journal of dairy science, 95(11), 6606-6623.

Saleh, W.M.M. (2019): Clinical and Hematological Profiles due to Cases of Minerals Deficiency in Local Ewes at Basra, Iraq. Advances in Animal and Veterinary Sciences, 7(4), 315320. doi:10.17582/journal.aavs/ 2019/ 7.4.315.320.

Shen, X. and Song, C. (2021): Responses of Chinese Merino Sheep (Junken Type) on Copper-Deprived Natural Pasture. Biol Trace Elem Res, 199(3), 989- 
995. doi:10.1007/s12011-020-02214-

8.

Slamova, R.; Trckova, M.; Vondruskova, H.; Zraly, Z. and Pavlik, I. (2011): Clay minerals in animal nutrition. Applied Clay Science, 51(4), 395-398.

Sloup, V.; Jankovská, I.; Nechybová, S.; Peřinková, $P$. and Langrová, I. (2017): Zinc in the animal organism: a review. Scientia Agriculturae Bohemica, 48(1), 13-21.

Song, C. and Shen, X. (2020): Effects of Environmental Zinc Deficiency on Antioxidant System Function in Wumeng Semi-fine Wool Sheep. Biol Trace Elem Res, 195(1), 110-116. doi:10.1007/s12011-019-01840-1.

Theobald, H.E. (2005): Dietary calcium and health. Nutrition Bulletin, 30(3), 237-277.

Thorndyke, M.P.; Guimaraes, O.; Tillquist, N.M.; Zervoudakis, J.T. and Engle, T.E. (2021): Molybdenum Exposure in Drinking Water Vs Feed Impacts Apparent Absorption of Copper Differently in Beef Cattle Consuming a High-Forage Diet. Biol Trace Elem Res, 199(8), 2913-2918. doi:10.1007/ s12011-020-02440-0

Tuncer, S.S.; Denizhan, V. and Kozat, S. (2020): Investigation of Serum and Wool Levels of Cobalt, Manganese, Selenium and Zinc in LiverTrematode-Infected Sheep. Kocatepe Vet J, 13(2), 185-191.

Vázquez-Armijo, J.F.; Rojo, R.; López, D.; Tinoco, J.L.; González, A.; Pescador, N. and Domínguez-Vara, I.A. (2011): Trace elements in sheep and goats reproduction: a review. Tropical and Subtropical Agroecosystems, 14(1), 1-13.

Vorland, C.J.; Stremke, E.R.; Moorthi, R.N. and Hill Gallant, K.M. (2017): Effects of Excessive Dietary
Phosphorus Intake on Bone Health. Curr Osteoporos Rep, 15(5), 473482. doi:10.1007/s11914-017-0398-4.

Wang, D.S.; Zhang, R.Y.; Zhu, W.Y. and Mao, S.Y. (2013): Effects of subacute ruminal acidosis challenges on fermentation and biogenic amines in the rumen of dairy cows. Livestock Science, 155(2-3), 262-272.

Wasilewski, G.B.; Vervloet, M.G.; and Schurgers, L.J. (2019): The BoneVasculature Axis: Calcium Supplementation and the Role of Vitamin K. Front Cardiovasc Med, 6, 6. doi:10.3389/fcvm.2019.00006.

Whitehead, D.C. (1979): Iodine in the U.K. Environment with Particular Reference to Agriculture. Journal of Applied Ecology, 16(1), 269-279.

WHO. (1971): International standards for drinking-water. third edition. world health organization geneva.

Williams, C.L. and Smith, S.M. (2018): Calcium dependence of spontaneous neurotransmitter release. J Neurosci Res, 96(3), 335-347. doi:10.1002/ jnr.24116.

$W u$, T.; Song, M. and Shen, X. (2020): Seasonal Dynamics of Copper Deficiency in Wumeng Semi-Fine Wool Sheep. Biol Trace Elem Res, 197(2), 487-494. doi:10.1007/s12011019-02018-5.

Yano, F.; Yano, H. and Breves, G. (1991): Calcium and phosphorus metabolism in ruminants Physiological aspects of digestion and metabolism in ruminants (pp. 277-295): Elsevier.

Yatoo, M.I.; Saxena, A.; Jhambh, R.; Nabi, S.; Melepad, D.P.; Kumar, P.; Dimri, U. and Sharma, M.C. (2013): Status of Trace Mineral Deficiency in Sheep and Goat in Kashmir Valley. Res. J. Vet. Pract, 1(4), 43-45. 


\section{دراسة إكلينيكية علي تأثير النقص الغذائي علي الحالة الصحية في الأغنام في محافظة الوادي الجديد صلاح عبل المحسن جلبط ، أسعاء محمود عبل اللهه ، محد عبل العزيز برهومة ، مروة الزفتاوي}

E-mail: marwa@vet.nvu.edu.eg; marwa_3_1983@yahoo.com Assiut University web-site: www.aun.edu.eg

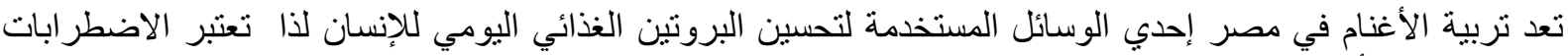

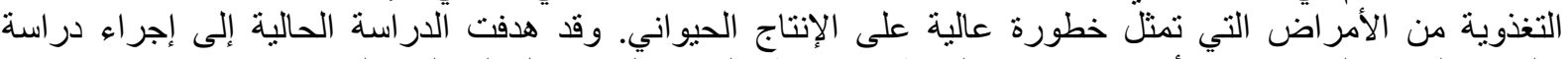

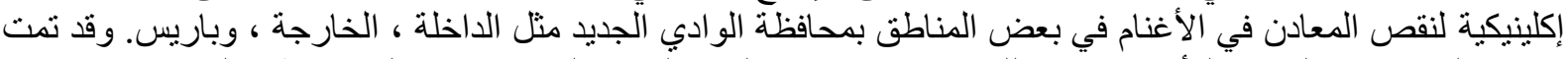

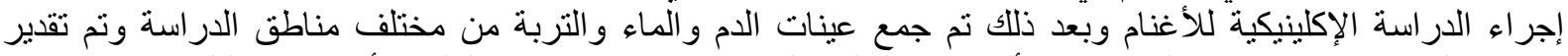

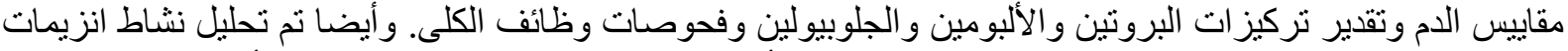

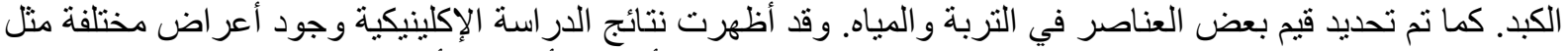

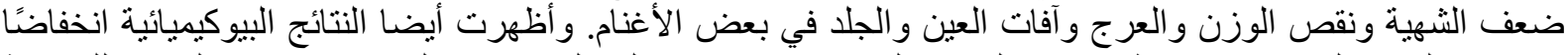

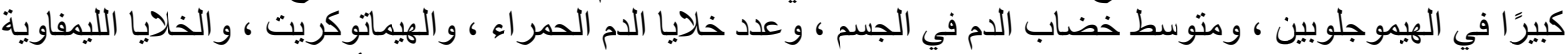

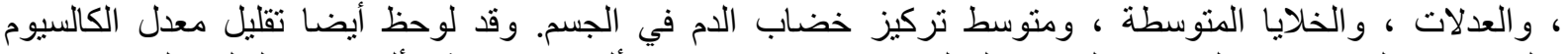

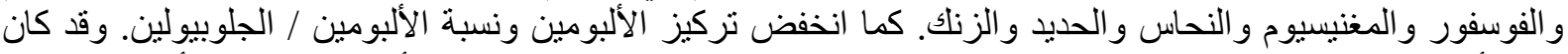

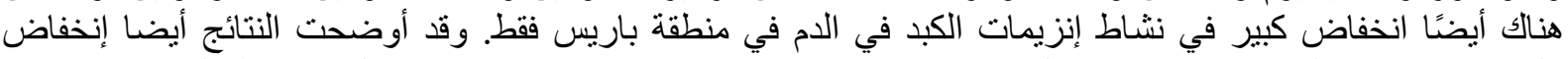

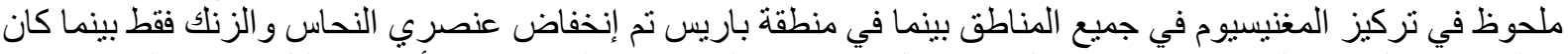

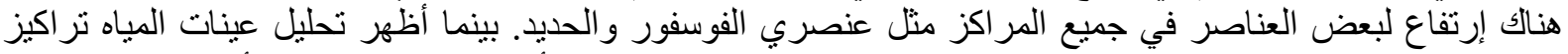

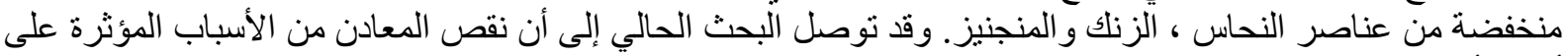
أداء الأغنام و إنتاجها وتكاثر ها في محافظة الو ادي الجنائ. 